\title{
Protein Patched Homolog 2
}

National Cancer Institute

\section{Source}

National Cancer Institute. Protein Patched Homolog 2. NCI Thesaurus. Code C34098.

Protein patched homolog 2 (1203 aa, 131 kDa) is encoded by the human PTCH2 gene.

This protein plays a role in hedgehog signaling pathways. 